\title{
Carbonylation of glycolytic proteins is a key response to drug-induced oxidative stress and apoptosis
}

\author{
K England ${ }^{1}, C^{\prime}{ }^{\prime}$ Driscoll $^{1}$ and TG Cotter ${ }^{*, 1}$ \\ 1 Tumour Biology Laboratory, Biosciences Institute, Department of \\ Biochemistry, University College Cork, Cork, Republic of Ireland \\ * Corresponding author: TG Cotter. Tel: + 35321 4901321; \\ Fax: + 35321 4904259; E-mail: t.cotter@ucc.ie
}

Received 10.4.03; revised 12.9.03; accepted 22.9.03; published online 21.11.03 Edited by G Melino

\begin{abstract}
Recent work has highlighted the importance of protein posttranslational modifications such as phosphorylation (enzymatic) and nitrosylation (nonenzymatic) in the early stages of apoptosis. In this study, we have investigated the levels of protein carbonylation, a nonenzymatic protein modification that occurs in conditions of cellular oxidative stress, during etopside-induced apoptosis of HL60 cells. Within $1 \mathrm{~h}$ of VP16 treatment, a number of proteins underwent carbonylation due to oxidative stress. This was inhibited by the antioxidant $\mathrm{N}$-acetyl-L-cysteine. Among the proteins found to be carbonylated were glycolytic enzymes. Subsequently, we found that the rate of glycolysis was significantly reduced, probably due to a carbonylation mediated reduction in enzymatic activity of glycolytic enzymes. Our work demonstrates that protein carbonylation can be rapidly induced through cytotoxic drug treatment and may specifically inhibit the glycolytic pathway. Given the importance of glycolysis as a source of cellular ATP, this has severe implications for cell function.

Cell Death and Differentiation (2004) 11, 252-260. doi:10.1038/ sj.cdd. 4401338

Published online 21 November 2003
\end{abstract}

Keywords: carbonylation; reactive oxygen species; protein oxidation; glycolysis, proteomics

Abbreviations: $A C N$, acetonitrile; $\mathrm{H}_{2}$ DCFDA, 2', $7^{\prime}$-dichlorodihydrofluorescein diacetate $\left(2^{\prime}, 7^{\prime}\right.$-dichlorofluorescin diacetate); NAC, N-acetyl-L-cysteine; VP16, etoposide; ROS, reactive oxygen species; TBS, Tris-buffered saline; TFA, trifluoroacetic acid; zVAD-fmk, Z-Val-Ala-Asp.fluoromethyketone.

\section{Introduction}

Apoptosis is a key process within multicellular organisms and is regulated through a number of different cell signalling pathways. It can be induced by a variety of stimuli, such as treatment with DNA-damaging agents, growth factor deprivation or binding of specific ligands to the so-called death receptors. All of these stimuli result in changes in posttranslational modifications of proteins that ultimately signal the cell to undergo apoptosis. These post translational modifications include a number of enzymatic modifications, such as protein phosphorylation, and cleavage of proteins, such as those targeted by the caspase pathway. There are also a number of nonenzymatic modifications that are equally important in the early stages of apoptosis and the importance of these has only recently been recognised. Nonenzymatic modifications include those induced by the reactive oxygen species (ROS), such as s-nitrosylation of caspases, that results in their inhibition. ${ }^{1}$ Identifying these nonenzymatic post-translational modifications during apoptosis has become key area of research in apoptosis, as we understand more about their roles within the cell.

ROS are constantly being generated within the cell by metabolic processes. ROS include free radicals such as the superoxide anion $\left(\mathrm{O}_{2}^{-}\right)$, hydoxyl radicals $(\mathrm{OH})$ and hydrogen peroxide $\left(\mathrm{H}_{2} \mathrm{O}_{2}\right)$. Superoxide can be generated by the reduction of molecular oxygen by NADPH oxidase. Further reduction of superoxide, by superoxide dismutase, results in the formation of $\mathrm{H}_{2} \mathrm{O}_{2} \cdot{ }^{2} \mathrm{ROS}$ can react with, and so damage, proteins, as well as lipids and carbohydrates. ROS can be generated within the cell as a response to cell stress and may act as secondary messengers ${ }^{3}$ to stimulate cell death from apoptosis or necrosis. ${ }^{4,5}$ Treatment of cells with many cytotoxic drugs has been shown to result in the production of ROS. For example VP16, or etoposide, is a topoisomerase II inhibitor; however, there are reports in the literature of VP16induced cell death being mediated through pathways independent of topoisomerase II inhibition, but dependant on ROS production. ${ }^{4,6}$ It is likely that the generation of ROS by cytotoxic drug treatment of cells results in nonenzymatic protein modifications that may play an important role in the early stages of apoptosis.

ROS can cause a number of nonenzymatic modifications of proteins, including carbonylation, o-tyrosine, chloro-, nitrotyrosine and dityrosine. Protein carbonylation is often used as a marker for oxidative stress ${ }^{7}$ and has been predominantly studied in association with ageing. ${ }^{8,9}$ Protein carbonylation can occur through direct oxidation of aminoacid side chains with ROS including $\mathrm{H}_{2} \mathrm{O}_{2}$ and $\mathrm{HOCl} .{ }^{10,11}$ Alternatively, amino acids can react with products of lipid peroxidation, such as 4-hydoxyl-2-nonenal. ${ }^{12-14}$ Carbonylation of proteins can also occur through reaction with reducing sugars or their oxidation products (glycation). ${ }^{11-13}$ As carbonylation involves the addition of a relatively large and reactive group onto the peptide backbone of a protein, it can have a variety of effects on the proteins properties, including covalent intermolecular cross-linking ${ }^{11,15}$ and cleavage to yield lower molecular weight species. ${ }^{14}$ Protein carbonylation can modify the rate of protein degradation, with some proteins showing increased and others reduced turnover. ${ }^{8,15-20}$ Perhaps most significantly, carbonylation of a protein can also reduce its activity, ${ }^{21}$ for example glutamine synthase exposed to metal catalysed oxidation has reduced enzyme activity. ${ }^{22}$ Consequently, cells that have large 
numbers of protein carbonyls may be expected to have impaired function.

Although nonenzymatic protein modifications such as protein carbonylation have been known about for some time, until recently it was not possible to easily identify the proteins that were susceptible to these modifications. However, recent advances in 2D-gel electrophoresis and proteomics have led to renewed interest in the field as it becomes possible to identify the proteins that are modified in this way. ${ }^{23-25} \mathrm{~A}$ number of interesting papers have shown that during ageing, protein oxidation in response to ROS are not random, but that some proteins are more susceptible than others. ${ }^{26}$ In the case of drosophilae flight muscle, only aconitase and adenine nucleotide translocase showed any increase in carbonylation with age, ${ }^{26}$ and in mouse plasma ageing-associated protein oxidation was only seen in two proteins, albumin and transferrin. ${ }^{27}$ In the case of more acute cell stress, such as during the early stages of apoptosis, there have also been significant recent advances demonstrating regulation of metabolic pathways through nonenzymatic protein modifications. For example, blastocysts exposed to high glucose levels undergo apoptosis showed ROS production and also showed a specific downregulation of the rate of glycolysis. ${ }^{28}$ It has also been shown that oxidative stress can induce a temporary block of glycolysis in U937 cells through ADP ribosylation of glycolytic enzymes. ${ }^{29}$ These interesting recent developments led us to ask whether we could identify, using proteomic methods, evidence of protein carbonylation in the early stages of apoptosis, which may contribute to apoptosis through modulation of specific proteins.

\section{Results}

\section{VP16 induced apoptosis in HL60 cells}

HL60 cells were treated with VP16 at $5 \mu \mathrm{g} / \mathrm{ml}$ for time points up to and including $4 \mathrm{~h}$. Flow cytometry analysis revealed that at $4 \mathrm{~h}$ of treatment, $50 \%$ of the cells are dead by apoptosis (apoptosis was measured by scoring morphological analysis of Rapi-Diff-stained cytospins, data not shown) (Figure 1a). Western blot analysis showed that caspase 3 was activated after $3 \mathrm{~h}$ of VP16 treatment as shown by the formation of cleavage products (Figure 1b). Pre-treatment with the caspase inhibitor zVAD reduced VP16-induced apoptosis in HL60 cells to control levels (Figure 1c), demonstrating that VP16-induced cell death is caspase dependent.

\section{ROS signalling is important for VP16-induced cell death in HL60 cells}

Production of ROS is a common feature of treatment of cells with cytotoxic drugs and can result in modifications of proteins and lipids. We therefore investigated the generation of ROS in VP16-treated HL60 cells. 2',7'-dichlorodihydrofluorescein diacetate ( $2^{\prime}, 7^{\prime}$-dichlorofluorescin diacetate) ( $\left.\mathrm{H}_{2} \mathrm{DCFDA}\right)$ (Molecular Probes) was used to examine peroxide production in $\mathrm{HL} 60$ cells by flow cytometry. $\mathrm{H}_{2} \mathrm{O}_{2}$ production was detected after 15 min of VP16 treatment in HL60 cells (Figure $2 \mathrm{a}$ and $\mathrm{b})$. The rapid increase in peroxide levels can be reduced to control levels by pretreatment with the antioxidant $\mathrm{N}$-acetyl-L-cysteine (NAC). The treatment of cells with $30 \mu \mathrm{M}$
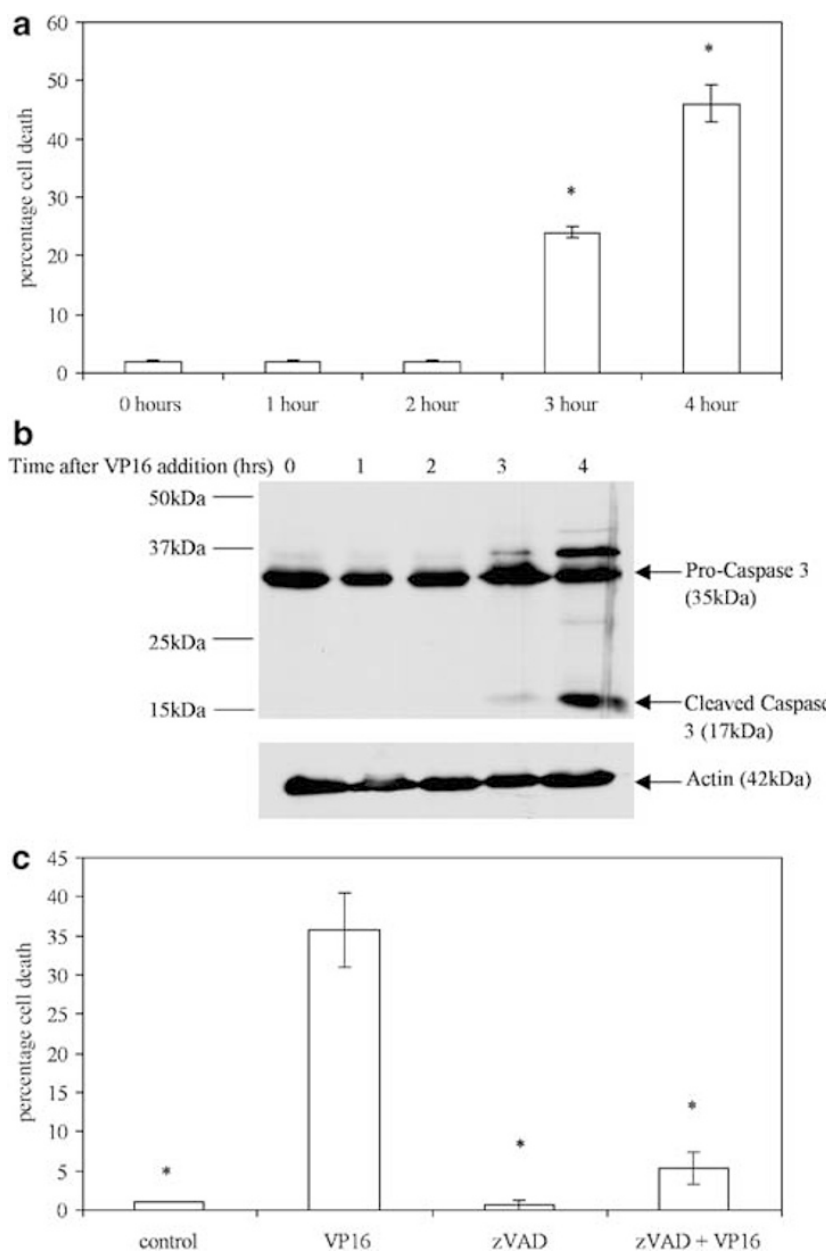

Figure 1 VP16 treatment of HL60 cells causes caspase 3 activation and apoptosis. (a) Graphical representation of PI incorporation by flow cytometry analysis showing that treatment of HL60 cells with $5 \mu \mathrm{g} / \mathrm{ml} \mathrm{VP16}$ resulted in approximately $50 \%$ cell death. Samples that show statistically significant increases in cell death as compared to untreated control cells, as demonstrated by t-test analysis $(P<0.05)$ and indicated by an asterisk. (b) Western blot analysis showed procaspase $3(35 \mathrm{kDa})$ is cleaved to produce active caspase 3 (17 kDa) after $3 \mathrm{~h}$ of treatment of HL60 cells with $5 \mu \mathrm{g} / \mathrm{ml}$ VP16. (c) Graphical representation of $\mathrm{PI}$ incorporation as detected by flow cytometry showing that treatment of HL60 cells with $20 \mu \mathrm{M}$ zVAD prior to addition of VP16 resulted in a reduction in cell death after $4 \mathrm{~h}$. Samples that show statistically significant decreases in cell death as compared to VP16-treated cells, as demonstrated by ttest analysis $(P<0.05)$ and are indicated by an asterisk

peroxide as a positive control also resulted in an increase in peroxide detected by the method, which could be reduced to control levels by pretreatment with NAC (Figure 2b). Superoxide levels in HL60 cells were also shown to be increased upon VP16 treatment (data not shown). Pretreatment with NAC significantly reduced VP16-induced cell death (approximately $50 \%$ reduction), demonstrating that $\mathrm{ROS}$ are important in VP16-induced cell death of HL60 cells (Figure 2c). Cell death induced by the addition of peroxide was also significantly reduced by the pretreatment of NAC (Figure 2c). Again, apoptosis was confirmed using morphological analysis of Rapi-Diff-stained cytospins. Further evidence of oxidative stress within VP16-treated cells was demonstrated by the reduction of the ratio of GSH to GSSG levels within HL60-treated cells (Figure 2d). The decrease in GSH seen 
over time is likely to be due to GSH being pumped out of the cell, particularly after the activation of caspases.

\section{Detection of protein carbonylation in VP16-treated HL60 cells}

ROS production in cells can result in a number of protein modifications such as carbonylation. We therefore investi-
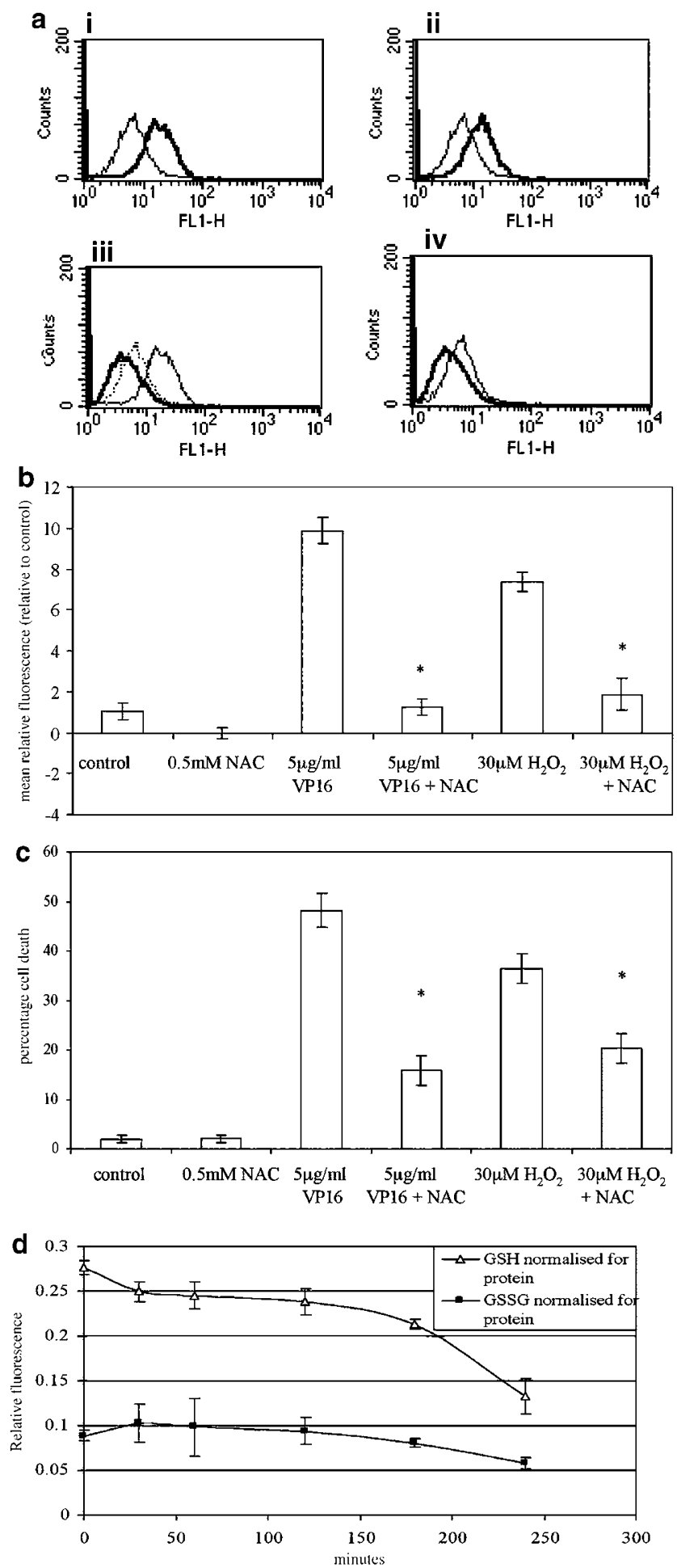

gated whether protein carbonylation, which can be used as a marker of oxidative stress, was increased in $5 \mu \mathrm{g} / \mathrm{ml}$ VP16treated HL60 cells and $30 \mu \mathrm{M} \mathrm{H}_{2} \mathrm{O}_{2}$-treated cells. Carbonylation was measured spectrophotometrically as described by Levine, $1984,{ }^{30}$ this assay showed an increase in protein carbonylation with $5 \mu \mathrm{g} / \mathrm{ml}$ VP16 (Figure 3a). As a positive control, we also used this method to demonstrate an increase in protein carbonylation in cells treated with $30 \mu \mathrm{M} \mathrm{H}_{2} \mathrm{O}_{2}$ (data not shown). Protein carbonylation was detected by western blotting for DNPH-modified proteins separated by 2D-gel electrophoresis. ${ }^{24,31}$ This method detected significant increases in protein carbonylation in HL60 cells after 1-h VP16 treatment (Figure 3b). Figure $3 c$ shows that pretreatment with the antioxidant NAC reduced VP16-induced protein carbonylation to control levels (i), demonstrating that, in this case, carbonylation is a result of ROS and it most likely is not the result of glycation. We also demonstrate an increase in protein carbonylation induced by treatment of HL60 cells with $30 \mu \mathrm{M} \mathrm{H}_{2} \mathrm{O}_{2}$ for $1 \mathrm{~h}$ (ii). A negative control demonstrating the specificity of the antibody for DNPH-modified proteins is also shown (iii). By matching 2D Western blots (Figure 3b) with silver-stained master gels, we were able to determine the identification of several carbonylated proteins. We have also employed immunoprecipitation of carbonyl-modified proteins to isolate carbonylated proteins (Figure 3d) for MALDI TOF m/ $s$ fingerprinting. This immunoprecipitation method can distinguish the difference in carbonylation levels between control and treated cells (i). Other negative controls are also shown to show the specificity of this approach (ii). Proteins that we find in 2D-gels of DNPH immunoprecipitates (iii) are compared with Western blots to confirm that differences in levels of their carbonylation are seen between control and VP16-treated cells. Proteins that we have identified to be carbonylated in response to VP16 treatment of HL60 cells are listed in Table 1. These include actin, a well-documented target of protein carbonylation. ${ }^{32,33} \mathrm{~A}$ surprising and rather interesting finding was that a number of the proteins identified as carbonylated in response to VP16 treatment are glycolytic enzymes; triose phosphate isomerase, phosphoglycerate mutase, $\alpha$ enolase

Figure 2 VP16-induced apoptosis of HL60 cells resulted in the production of ROS after 15 min. (a) $\mathrm{H}_{2} \mathrm{O}_{2}$ detection in VP16 treated $\mathrm{HL} 60$ cells as shown by analysis of cells treated with $5 \mu \mathrm{g} / \mathrm{ml}$ VP16 for $15 \mathrm{~min}$; (i) thin line, control cells; thick line, VP16-treated cells; (ii) thin line, control cells; thick line cells treated with $0.03 \mathrm{mM} \mathrm{H}_{2} \mathrm{O}_{2}$; (iii) dotted line, control cells, thin line, VP16-treated cells, thick line, cells pretreated with NAC and treated with VP16; (iv) thin line, control cells, thick line, NAC-treated cells. (b) Histogram showing $\mathrm{H}_{2} \mathrm{O}_{2}$ detection in VP16 treated $\mathrm{HL} 60$ cells. The Mean relative fluorescence for $\mathrm{H}_{2}$ DCFDA Facs analysis is shown for cells treated with $5 \mu \mathrm{g} / \mathrm{ml} \mathrm{VP16}$ or $30 \mu \mathrm{M} \mathrm{H}_{2} \mathrm{O}_{2}$ for 15 min and cells pretreated with NAC. Samples that show statistically significant decreases in peroxide as compared to the corresponding treated cells, as demonstrated by ttest analysis $(P<0.05)$, for example, NAC-treated VP16 cells as compared to VP16-treated cells, and NAC and peroxide as compared to peroxide-treated cells are indicted by an asterisk. (c) Graphical representation of PI incorporation as detected by flow cytometry showing that VP16-induced cell death of HL60 cells after $4 \mathrm{~h}$ can be reduced by pretreatment with $0.5 \mathrm{mM}$ NAC. Samples that show statistically significant decreases in cell death as compared to the corresponding treated cells, as demonstrated by t-test analysis $(P<0.05)$, for example, NAC treated VP16 cells as compared to VP16 treated cells, and NAC and peroxide as compared to peroxide-treated cells are indicated by an asterisk. (d) The ratio of GSH (reduced glutathione) and GSSG (oxidised glutathione) was reduced in VP16-treated HL60 cells. GSH and GSSG were measured as described in Materials and Methods 

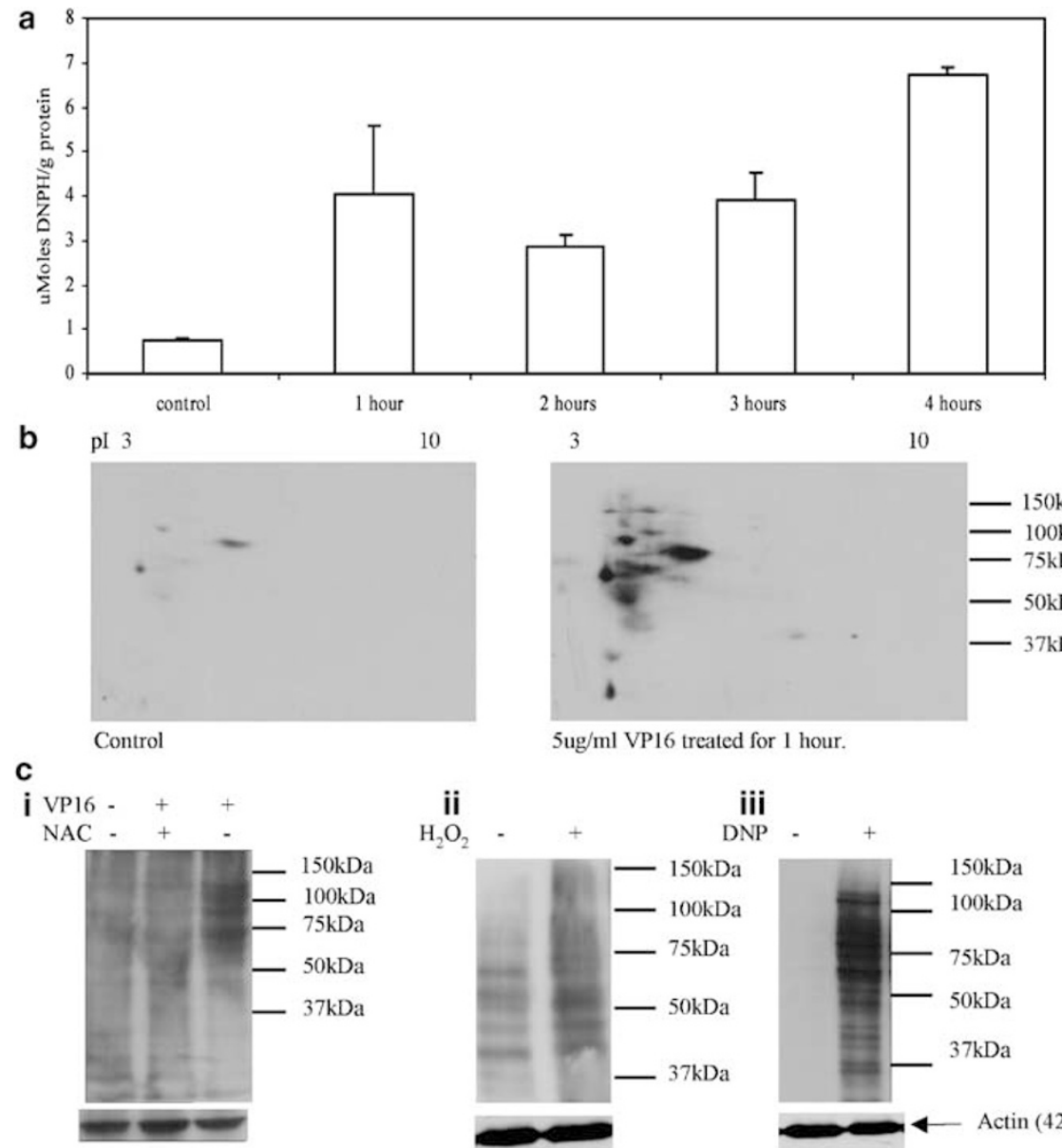

10

3

10

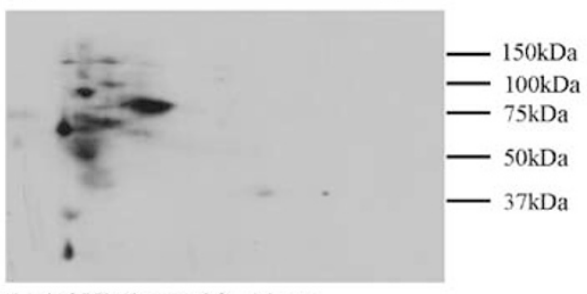

$5 u g / m l$ VP16 treated for 1 hour.
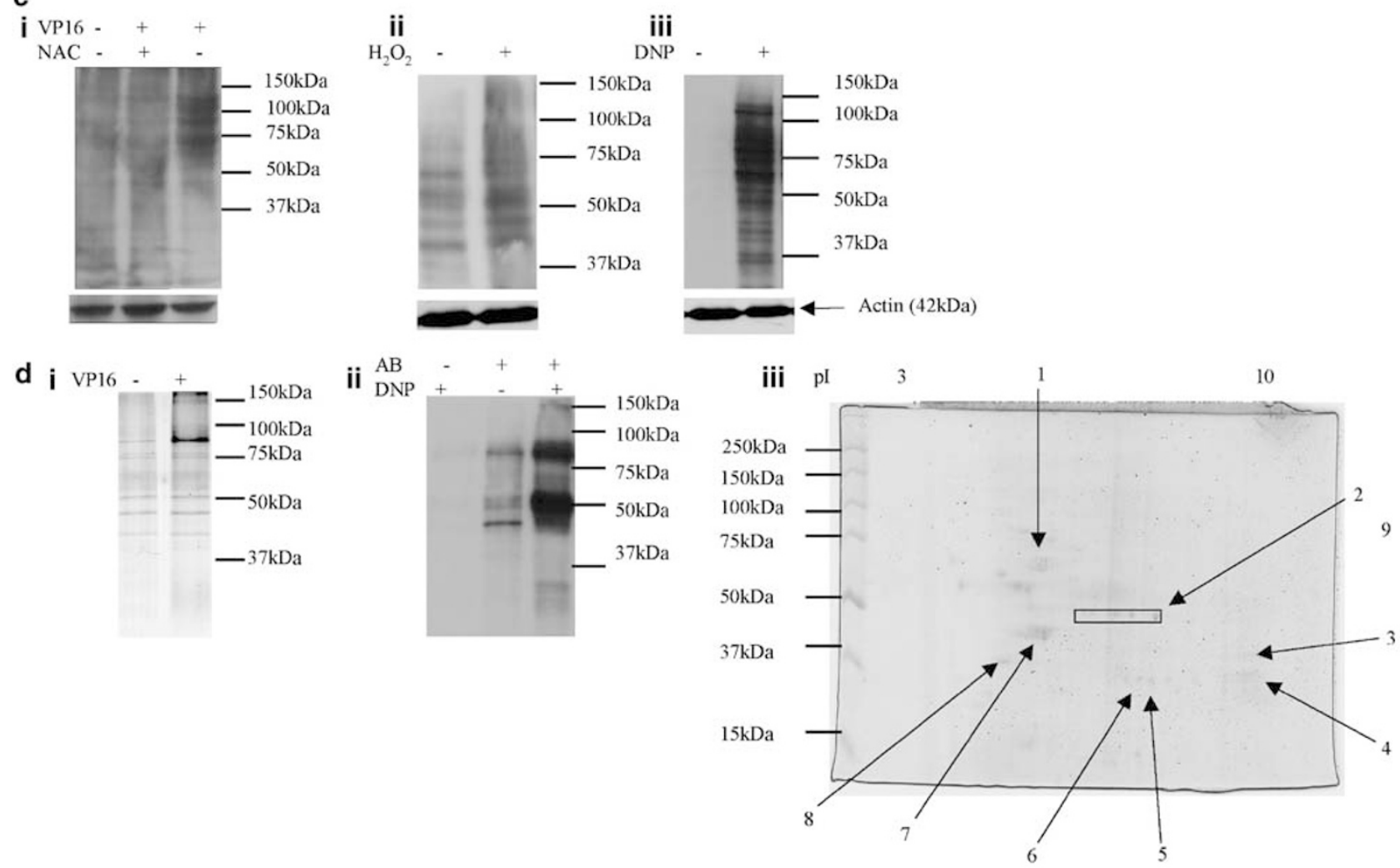

Figure 3 Protein carbonylation is increased in VP16 treated HL60 cells. (a) Histogram showing DNPH incorporation, as an indicator of protein carbonylation, was measured over time after the addition of $5 \mu \mathrm{g} / \mathrm{ml} \mathrm{VP16}$, by spectrophotometry, as described in the Materials and Methods (DNPH incorporation is $\mu$ moles/g protein). (b) After treatment for $1 \mathrm{~h}$ with $5 \mu \mathrm{g} / \mathrm{ml} \mathrm{VP16,} \mathrm{protein} \mathrm{was} \mathrm{extracted} \mathrm{and} \mathrm{any} \mathrm{carbonyl} \mathrm{groups} \mathrm{were} \mathrm{modified} \mathrm{by} \mathrm{the} \mathrm{reaction} \mathrm{with} \mathrm{DNP} \mathrm{as} \mathrm{described} \mathrm{in} \mathrm{Materials} \mathrm{and} \mathrm{Methods.}$ The proteins were then separated by 2D-gel electrophoresis and transferred to nitrocellulose. Carbonylated proteins were detected by probing with an anti-DNP antibody. (c) Detection of protein carbonylation by Western blotting to DNP-modified protein carbonyls. Actin is included as an equal loading control. (i) Protein carbonylation in response to VP16 treatment was reduced by pretreatment for $30 \mathrm{~min}$ with $0.5 \mathrm{mM} \mathrm{N}$-acetyl cysteine. (ii) Protein carbonylation is increased by treatment with $30 \mu \mathrm{M} \mathrm{H}_{2} \mathrm{O}_{2}$ for 4 hours. (iii) Western blot for DNP to VP16-treated cells $(5 \mu \mathrm{g} / \mathrm{ml}$ for $1 \mathrm{~h})$. The protein sample was split and treated with \pm DNPH as described in Materials and Methods, to demonstrate the specificity of the antibody for DNPH-modified proteins. (d) (i) Coomassie stained gel of DNP immunoprecipitates from control and VP16 treated cells $(5 \mu \mathrm{g} / \mathrm{ml}$ for $1 \mathrm{~h}$ ). (ii) To demonstrate the specificity of the DNP immunoprecipitations, incubations were carried out in the absence of the anti-DNP antibody, and with proteins that had not been treated with DNPH. (iii) DNP-modified proteins from VP16-treated HL60 cells were immunoprecipitated and resolved by 2Dgel electrophoresis. After Coomassie staining, protein spots were excised and analysed by MALDI TOF m/s peptide mass fingerprinting 
Table 1 Proteins that were identified as carbonylated, by either matching to master gels, or by peptide mass spectrometry fingerprinting of DNP-modified proteins immunoprecipitates, in VP16-treated HL60 cells are listed, alongside their functions and the number of peptides matched by peptide mass fingerprinting

\begin{tabular}{|c|c|c|c|}
\hline $\begin{array}{l}\text { Spot } \\
\text { Number }\end{array}$ & $\begin{array}{l}\text { Protein (accession } \\
\text { number) }\end{array}$ & Function & $\begin{array}{l}\text { No. matched } \\
\text { peptides }\end{array}$ \\
\hline 1 & $\begin{array}{l}\text { BiP (glucose } \\
\text { regulated protein } \\
\text { grp78) (p11021) }\end{array}$ & Chaperone & 10 \\
\hline 2 & $\alpha$ enolase (P06733) & Metabolism & 8 \\
\hline 3 & $\begin{array}{l}\text { Fructose bis- } \\
\text { phosphate aldolase } \\
\text { (P09972) }\end{array}$ & Metabolism & 5 \\
\hline 4 & $\begin{array}{l}\text { C-AMP-dependent } \\
\text { PDE (Q9NP56) }\end{array}$ & $\begin{array}{l}\text { Signal } \\
\text { transduction }\end{array}$ & 5 \\
\hline 5 & $\begin{array}{l}\text { Phosphoglycerate } \\
\text { mutase (P18669) }\end{array}$ & Metabolism & 8 \\
\hline 6 & $\begin{array}{l}\text { Triose phosphate } \\
\text { isomerase (P00938) }\end{array}$ & Metabolism & 11 \\
\hline 7 & Actin (P02570) & Cytoskeleton & 10 \\
\hline 8 & $\begin{array}{l}\text { Plexin B2 } \\
(20270190)\end{array}$ & $\begin{array}{l}\text { Transmembrane } \\
\text { receptor }\end{array}$ & 7 \\
\hline
\end{tabular}

and fructose bis-phosphate aldolase. The majority of proteins identified by the method are at a high abundance within the cell, possibly this high abundancy accounts for their susceptibility to carbonylation. It is also possible that this finding shows a limitation of the technique; as only relatively high abundancy proteins will be identified through coomassie staining of immunoprecipitations, and that future analysis of smaller cellular fractions will reveal more proteins of lower abundance that are susceptible to carbonylation. However, other high abundancy proteins, as detected on 2D-gels, do not show positive staining for carbonylation, demonstrating that there is selectivity in this approach.

\section{Glucose utilisation is decreased in VP16 treated- HL60 cells}

Carbonylation of proteins has been reported to severely impair their function, ${ }^{21,22}$ so as a number of glycolytic enzymes were shown to be carbonylated upon VP16 treatment of HL60 cells, it was important to measure the rate of glycolysis in VP16-treated cells. (As a control, we also assayed the percentage of glucose metabolised by the pentose phosphate pathways; as no enzymes from this pathway were seen to be carbonylated in VP16-treated cells.) The rate of glycolysis was measured by examining the rate of conversion of $5-{ }^{3} \mathrm{H}$ glucose to ${ }^{3} \mathrm{H}_{2} \mathrm{O}$, which is dependant on the rate of breakdown of glucose to phosphoenolpyruvate. The rate of the pentose phosphate pathway was measured by calculation of the ratio of breakdown of $1-{ }^{14} \mathrm{C}$ glucose and $6-{ }^{14} \mathrm{C}$ glucose to ${ }^{14} \mathrm{CO}_{2}$. These data show that the rate of glucose utilisation by HL60 cells was decreased significantly after $2 \mathrm{~h}$ of drug treatment, before any increase in apoptosis (Figure 4a). This time corresponded to the carbonylation of glycolytic proteins, which was seen after $1 \mathrm{~h}$ suggesting that protein carbonylation may be the mechanism by which glycolysis is down-regulated in VP16-treated cells. Analysis of the pentose phosphate pathway showed no decrease in activity, suggesting that the inhibition of glycolysis in VP16- treated cells is specific to that pathway (Figure 4b). The slight increase in activity of the pentose phosphate pathway may be explained by an attempt to produce more reducing power in the form of $\mathrm{NADP}^{+} \mathrm{H}^{+}$in an attempt to overcome the oxidative stress.

\section{Glucose deprivation of HL60 cells reduces VP16-induced cell death}

As glycolysis is the most common source for ATP in cultured cells, due to poor coupling between glycolysis and the TCA, ${ }^{34}$ we explored whether a reduction of glycolysis, through glucose deprivation, had any effect on the levels of VP16induced cell death. We also looked at whether growth in serum-free media had any effect on the susceptibility of these cells to VP16-induced apoptosis. HL60 cells were grown in glucose-free or serum-free media for $24 \mathrm{~h}$ prior to VP16 addition, this had no effect on basal levels of cell death, and did not cause cell cycle arrest (data not shown). HL60 cells grown in medium lacking glucose or serum showed reduced sensitivity to VP16 and peroxide-induced cell death (Figure 5), approximately $50 \%$ protection. Apoptosis was confirmed as the method of cell death by morphological analysis as before. This data suggest that inhibition of glycolysis reduces cellular apoptosis, possibly due to a lack of intracellular ATP that is required for apoptosis.

\section{Discussion and Conclusions}

Cytotoxic drugs mediate their effects through a multitude of signalling cascades, employing both enzymatic and nonenzymatic mechanisms. ROS generation is a common feature of cell stress, including treatment with cytotoxic drugs. Understanding the downstream effects of ROS is important in elucidating the mechanisms by which these agents induce cell death at the biochemical level. Here we have used the well-defined cell line HL60, treated with VP16, to look at a nonenzymatic protein modification during apoptosis. We confirmed that VP16-induced cell death in HL60 cells depends, at least in part, on the production of ROS, in particular $\mathrm{H}_{2} \mathrm{O}_{2}$. DNPH modification of carbonylated proteins can be detected using an antibody directed against DNP. This method, although indirect, is well established ${ }^{35}$ and we used it to demonstrate, that VP16 treatment of HL60 cells lead to carbonylation of a number of proteins within $1 \mathrm{~h}$. Our work also provides evidence that this protein carbonylation is mediated through ROS mechanisms rather than glycation, as it can be reduced by NAC pretreatment. It is possible that carbonylation in this case could be mediated through either direct oxidation of the amino acids, or through the Michael addition of lipid peroxides.

Among the carbonylated proteins in VP16-treated HL60 cells was actin, which has previously been reported to be carbonylated, and seems to be more susceptible to carbonylation than other cytoskeletal components. ${ }^{32,33}$ Interestingly we showed that a number of glycolytic enzymes, $\alpha$ enolase, triose phosphate isomerase, phosphoglycerate mutase and fructose bis-phosphate aldolase, were also carbonylated in VP16-treated HL60 cells. 

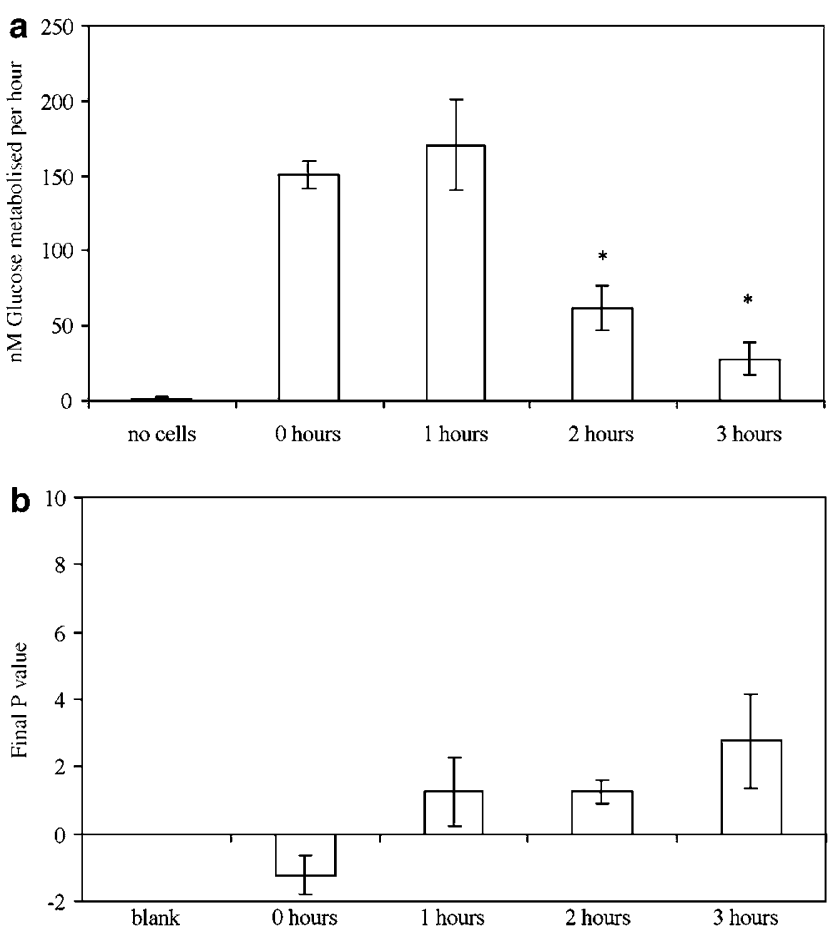

Figure 4 Glycolysis but not the pentose phosphate pathway is reduced in VP16-treated cells. (a) The rate of glucose metabolism ( $\eta \mathrm{M}$ per hour) was measured by the conversion of $5-{ }^{3} \mathrm{H}$ glucose to ${ }^{3} \mathrm{H}_{2} \mathrm{O}$. Samples in which the rate of glucose utilisation is significantly different to that of control cells are indicated by an asterisk. (b) The rate of the pentose phosphate pathway was measured by calculating the ratio of conversion of $1-\mathrm{C}^{14}$ glucose and $6-\mathrm{C}^{14}$ to ${ }^{14} \mathrm{CO}_{2}$ (the final $P$-value)

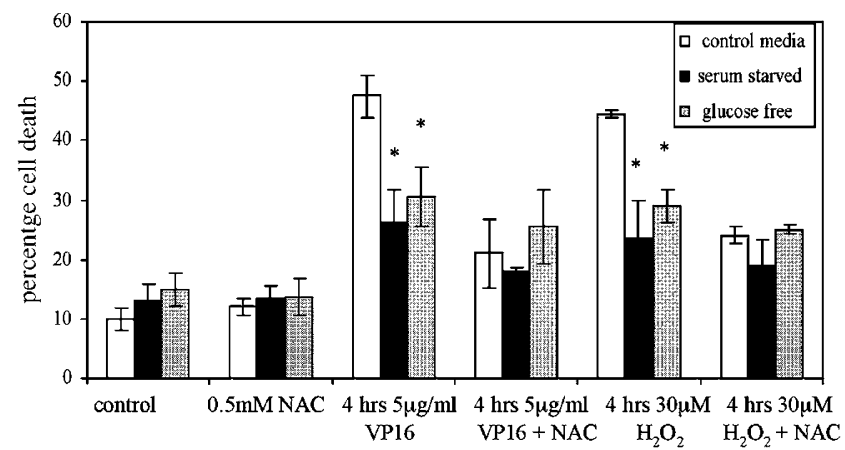

Figure 5 Graphical representation of $\mathrm{PI}$ incorporation by flow cytometry analysis showing that glucose deprivation and serum starvation of HL60 cells results in decreased susceptibility to VP16-induced apoptosis. HL60 cells were grown in either normal media, in media without serum, or in glucose-free medium for $24 \mathrm{~h}$ prior to the addition of $5 \mu \mathrm{g} / \mathrm{ml}$ VP16 or $30 \mu \mathrm{M} \mathrm{H}_{2} \mathrm{O}_{2} \pm 0.5 \mathrm{mM} \mathrm{NAC}$ for $4 \mathrm{~h}$. Apoptosis was confirmed by morphological analysis of Rapi-Diff-stained cytospins. Samples in which cell death is significantly different to corresponding treatments in normal growth media as shown by $t$-test analysis $(P<0.05)$ are indicated by an asterisk

Protein carbonylation has been reported to inhibit protein activity. ${ }^{36,37}$ This is not surprising given that carbonylation can involve the addition of a relatively large or charged molecule to the amino-acid side chain. We therefore decided to measure the rate of glycolysis, in which we see carbonylation, and the pentose phosphate pathway, for which we have no evidence of carbonylation, in VP16-treated HL60 cells. Our analysis showed that in VP16-treated HL60 cells, glucose utilisation was reduced dramatically after $2 \mathrm{~h}$, before cell death occurs. By contrast, the pentose phosphate pathway activity was not decreased. As we detected carbonylation of glycolytic proteins after $1 \mathrm{~h}$, it is likely that carbonylation of glycolytic enzymes is responsible for the decreased rate of glucose utilisation. This suggests a specific regulation of a metabolic pathway by a nonenzymatic reaction. Recent work looking at protein oxidation in ageing suggests that some proteins are more susceptible to protein carbonylation than others. This means that oxidative stress, causing protein carbonylation, may result in specific and predictable effects on cell behaviour.

There are other examples of the regulation of metabolism by oxidative and other cellular stresses. Mouse blastocytes exposed to high levels of D-glucose undergo apoptosis through oxidative stress mechanisms. These cells also show decreased glycolysis (but no decrease in pentose phosphate pathway activity), suggesting a specific oxidative response to reduce glycolysis. ${ }^{28}$ It has also been demonstrated that oxidative stress induces a temporary block in glycolysis through ADP ribosylation in U937 cells. ${ }^{29}$ Although this is not mediated through carbonylation, it does illustrate the potential of oxidative stress to specifically regulate a part of the metabolism. In bacteria, senescence induces carbonylation and several enzymes of the TCA cycle were found to be more susceptible to carbonylation than others. ${ }^{38}$ This evidence from the literature supports our suggestion that a nonenzymatic protein modification such as carbonylation can result in the reduction in activity of one metabolic pathway above another. In this case, a reduction of glycolysis due to protein carbonylation occurs during VP16-induced apoptosis.

There has recently been renewed interest in the role of metabolism in cell death, with recent literature providing evidence of the particular importance of glycolysis in apoptosis. The PI3 kinase/Akt survival pathway is, at least in part, mediating its effects through the regulation of glycolysis. ${ }^{39-43}$ There are also several studies documenting the effects of the inhibition of glycolysis on apoptosis. $^{29,39,41,42,44}$ Unfortunately, this evidence is often conflicting, with glucose deprivation inducing apoptosis in some cell systems while providing temporary protection from apoptosis in others. Recent findings show that inhibition of glycolysis with 2-deoxy glucose results in a rapid decrease in ATP levels, and that cell death is not immediate, or as rapid as in cells deprived of growth factors. ${ }^{40}$ Possibly this is because the levels of intracellular ATP are sufficient to allow apoptosis to occur as normal. Apoptosis is an energy-requiring process and decreasing intracellular ATP levels can result in a switch from apoptosis to necrosis in some instances. Inhibition of glycolysis through the addition of 2-deoxyglucose increases the efficiency of some cytotoxic agents. ${ }^{39,45}$ In our system, it seems that glucose or serum deprivation does protect the HL60 cells, to some degree, from apoptosis. It is possible that the decrease in glycolysis seen in VP16-treated cells is a failed cell defence mechanism. Inhibition of glycolysis may result in the cell being in an inert, inactive and so protected state. It may also protect from apoptosis by reducing levels of 
ATP such that apoptosis is inhibited - although it is likely that this would result only in a delay in apoptosis rather than its complete inhibition. ${ }^{29}$ Also, carbonylation is an irreversible modification and therefore even if this were the case it would not be possible for the cell to become reactivated upon the improvement of its environment, except through new protein synthesis. Exposure of FL5 cells to VP16 over $72 \mathrm{~h}$ resulted in a decrease in the rate of glycolysis, although in this case it is likely that the decrease in glycolysis is due to downregulation at the RNA level. ${ }^{46}$ This is a further evidence of cells downregulating glycolysis as a defence mechanism, to protect the cell from apoptosis.

This paper demonstrates the potential importance of protein carbonylation apoptosis. It is the first to show carbonylation of glycolytic enzymes due to drug treatment and demonstrates that, similar to recent work in the ageing field, protein carbonylation during the induction of apoptosis may result in the modification of a restricted number of proteins, resulting in profound effects on the behaviour of the cell.

\section{Materials and Methods}

All chemicals were from Sigma (Poole, Dorset, UK) unless otherwise indicated.

\section{Antibodies}

The anti-caspase 3 antibody (Cell Signalling, Beverley, MA, USA) was used at $1: 1000$ dilution. The anti-actin antibody (Sigma, Poole, Dorset, UK) used for equal loading controls was used at 1:5000 dilution. The antiDNP antibody (Dako, Ely, Cambs, UK) was used at 1:5000 dilution.

\section{Cell culture and cytotoxic drug treatment}

HL60 cells were maintained in RPMI 1640 supplemented with $10 \%$ foetal calf serum (FCS), 1\% penicillin-streptomycin and $2 \mathrm{mM}$ L-glutamine (Gibco Brl, Paisley, UK). Cells were grown at $37^{\circ} \mathrm{C}$ in a humidified $5 \% \mathrm{CO}_{2}$ atmosphere. VP16 was prepared in DMSO. For induction of apoptosis, $5.0 \times 10^{5} \mathrm{cells} / \mathrm{ml}$ were incubated for the appropriate time and drug at $37^{\circ} \mathrm{C}$. Treatment with NAC (Calbiochem, Nottingham, UK) and ZVAD (Enzyme System Products, CA, USA) was for $30 \mathrm{~min}$ prior to the addition of VP16 or $\mathrm{H}_{2} \mathrm{O}_{2}$. Cells were treated with $0.5 \mathrm{mM} \mathrm{NAC}$ for 30 min prior to drug addition. For glucose deprivation, cells were grown in glucose-free RPMI supplemented with $10 \%$ dialysed FCS, penicillin/streptomycin and L-glutamine as above; for serum starvation, cells were grown in the above media in the absence of FCS.

\section{Analysis of cell death \\ Cell viability and apoptosis were assessed by propidium iodide (PI) uptake on a FACScan (Becton and Dickinson, Oxford, UK) flow cytometer at 590(FL-2) nm. Cells were incubated with $5 \mu \mathrm{g} / \mathrm{ml}$ PI prior to analysis. The criteria for cell death were based on changes in the light scattering properties of dead cells due to shrinkage and increased granularity as well as increased permeability to $\mathrm{PI}$. Apoptosis was confirmed by morpholo- gical analysis of stained Cytospin preparations. Rapi-diff (Diachem International Ltd., West Gillibrands, Lancashire, UK)-stained centrifuged cell preparations were examined for the morphological characteristics of}

apoptosis. Apoptosis was quantified by counting three independent microscopic fields with at least 100 cells per field.

\section{FACS analysis of ROS generation}

HL60 cells at $5 \times 10^{5}$ were treated with $5 \mu \mathrm{g} / \mathrm{ml}$ VP16 for the indicated times and $100 \mu \mathrm{M} \mathrm{H}_{2}$ DCFDA, (Molecular Probes, Leiden, The Netherlands) or DHE, dihydroethidium (hydroethidine) (Molecular Probes), was added $30 \mathrm{~min}$ before analysis on a FACScan (Becton and Dickinson, Oxford, UK) with excitation and emission spectra set at 488 and $530 \mathrm{~nm}$, and on CellQuest software. $\mathrm{H}_{2} \mathrm{O}_{2}$ and $\mathrm{O}_{2}{ }^{-}$. production was calculated by the increase in mean fluorescence.

\section{Fluorometric determination of oxidised and reduced glutathione}

HL60 cell pellets $\left(1 \times 10^{6}\right)$ were resuspended in $500 \mu$ l NaP-EDTA buffer (0.1 M. sodium phosphate, $5 \mathrm{mM}$ EDTA pH8.0). The cells were flash frozen, rapidly thawed, mixed thoroughly on a vortex and centrifuged for $300 \mathrm{~g}$ for $5 \mathrm{~min}$ at $5^{\circ} \mathrm{C}$. For protein determination, $100 \mu \mathrm{l}$ was used for the BioRad protein determination assay (BioRad, Hemel Hempstead, Herts., UK). Protein was precipitated by the addition of $100 \mu \mathrm{HPO}_{3}$ (25\% in NaPEDTA buffer) to $400 \mu$ of protein. Samples were vortexed for $5 \mathrm{~min}$ and centrifuged at $15000 \mathrm{~g}$ for $15 \mathrm{~min}$. For GSSG determination, $10 \mu \mathrm{l}$ of this supernatant was incubated with $4 \mu \mathrm{l}$ of $\mathrm{N}$-ethyl-maleimide $(40 \mathrm{mM}$ in the $\mathrm{NaOH}$ buffer) for $30 \mathrm{~min}$ at room temperature, $36 \mu \mathrm{l}$ of $0.1 \mathrm{M} \mathrm{NaOH}$ was then added and the sample was vortexed and stored on ice. Before analysis, this was made up to $200 \mu \mathrm{l}$ in $\mathrm{NaOH}$. For GSH determination, $10 \mu$ l of sample with $10 \mu$ l of on-phthaladehyde $(1 \mathrm{mg} / \mathrm{ml}$ in methanol) was added to $180 \mu$ l of NaP-EDTA buffer. Standards were set up, GSH in NaPEDTA buffer and GSSG in $0.1 \mathrm{M} \mathrm{NaOH}$. Fluorescence was monitored after $15 \mathrm{~min}$ on a Perkin-Elmer Luminescence spectrophotometer 2S 50B (Perkin Elmer, MA, USA) at $420 \mathrm{~nm}$ emission after excitation at $350 \mathrm{~nm}$.

\section{DNPH assay to detect protein carbonylation}

This was carried out according to the method of Levine et al. ${ }^{30}$. Briefly, $1 \mathrm{mg}$ of protein was dried down in a vacuum centrifuge before resuspending in $500 \mu \mathrm{l}$ at $10 \mathrm{mM} \mathrm{DNPH}$ in $2 \mathrm{M} \mathrm{HCl}$ and incubated for $1 \mathrm{~h}$ at room temperature. Protein was precipitated by the addition of $20 \%$ TCA and after centrifugation in a bench top centrifuge and washed three times in $20 \%$ TCA. The precipitated protein was resuspended in $6 \mathrm{M}$ guanidine $\mathrm{HCl}, 20 \mathrm{mM}$ potassium phosphate $\mathrm{pH} 6.5, \mathrm{pH}$ 2.3. Samples were read at 360-370 nm, with an absorption coefficient of $22000 \mathrm{M} / 1 \mathrm{~cm}$. Protein was quantified using the BioRad protein assay.

\section{Detection of protein carbonylation}

Protein was extracted into $40 \mathrm{mM}$ Tris with $10 \mu \mathrm{g} / \mu \mathrm{l}$ aprotinin, $10 \mu \mathrm{g} / \mathrm{ml}$ leupeptin, $2 \mathrm{mM}$ AEBSF, $50 \mathrm{mM} \mathrm{NaF}, 5 \mathrm{mM}$ Na pyrophosphate, $10 \mu \mathrm{M} \mathrm{Na}$ orthovanadate and $100 \mu \mathrm{l}$ cell extract was treated with $20 \mu \mathrm{l}$ of $10 \mathrm{mM}$ 2, 4dinitrophenyl hydrazine (DNP) in $2 \mathrm{M} \mathrm{HCl}$ for $30 \mathrm{~min}$ at $18^{\circ} \mathrm{C}$. For negative controls, samples were treated with $\mathrm{HCl}$ without DNPH. Protein was precipitated by the addition of an equal volume of ice-cold 10\% TCA and incubation on ice for $30 \mathrm{~min}$. Protein was pelleted by centrifugation at full speed in a bench top centrifuge for $5 \mathrm{~min}$ and the protein pellet resuspended in 2D-gel lysis buffer as below for resolving on 2D-gels or immunoprecipitation buffer as appropriate. Protein determination was carried out using the BioRad protein determination assay as above. 


\section{Immunoprecipitations}

Equal amounts of protein $(200 \mu \mathrm{g})$ were resuspended in immunoprecipitation buffer $(10 \mathrm{mM}$ Tris $\mathrm{HCl}, 150 \mathrm{mM} \mathrm{NaCl}, 1 \mathrm{mM}$ EDTA, 0.5\%. SDS, $1 \%$ TX-100, $1 \%$ deoxycholic acid, $10 \mu \mathrm{g} / \mathrm{ml}$ aprotinin, $10 \mu \mathrm{g} / \mathrm{ml}$ leupeptin, $2 \mathrm{mM}$ AEBSF, $50 \mathrm{mM} \mathrm{NaF}, 5 \mathrm{mM}$ Na pyrophosphate, $10 \mu \mathrm{M}$ sodium orthovanadate $\mathrm{pH} 7.4$ ), precleared for $2 \mathrm{~h}$ by the addition of Protein $A$ sepharose beads and then incubated overnight with $10 \mu$ lof antibody. The pellet was washed twice with IP buffer before resuspending in 2D-gel lysis buffer. For negative controls samples were incubated without DNPH, or without antibody, or an irrelevant antibody.

\section{D-gel electrophoresis}

HL60 cells ( $10 \mathrm{ml}$ at $5 \times 10^{5}$ cells $/ \mathrm{ml}$ ) were spun down at $1000 \mathrm{~g}$ for $5 \mathrm{~min}$, washed in $0.25 \mathrm{M}$. sucrose before washing and resuspending in $40 \mathrm{mM}$ Tris with phosphatase and protease inhibitors added $(10 \mu \mathrm{g} / \mu \mathrm{l}$ aprotinin, $10 \mu \mathrm{g} / \mathrm{ml}$ leupeptin, $2 \mathrm{mM}$ AEBSF, $50 \mathrm{mM} \mathrm{NaF}, 5 \mathrm{mM}$ Na pyrophosphate, $10 \mu \mathrm{M}$ Na orthovanadate). Samples were sonicated and spun at $15000 \mathrm{~g}$ in a bench top centrifuge for $15 \mathrm{~min}$. Protein was quantified as above and $20 \mu \mathrm{g}$ was suspended in $1 \mathrm{M}$ thiourea, $8 \mathrm{M}$ Urea, $4 \%$ CHAPS, $2 \mathrm{mM}$ tributylphosphine with the addition of the appropriate carrier ampholytes, pH3-10 (Amersham Bioscicences, Chalfont St. Giles, Bucks., UK). Isoelectric focusing was carried out on an IPG Phor using $7 \mathrm{~cm}$ pH 3-10 Immoboline Dry Strip Gels (Amersham) using a gradient from 500 to $5000 \mathrm{~V}$ to give a total of $8750 \mathrm{vhs}$. After isoelectric focusing, gels strips were incubated for $14 \mathrm{~min}$ in $50 \mathrm{mM}$ Tris $\mathrm{pH} 8.8,6 \mathrm{M}$ urea, $30 \%(\mathrm{v} / \mathrm{v})$ glycerol, $2 \%$ SDS, $2 \%$ DTT, then for 4 min in $50 \mathrm{mM}$ Tris $\mathrm{pH} 8.8,6 \mathrm{M}$ urea, $30 \%$ (v/v) glycerol, $2 \%$ SDS, $2.5 \%$ iodoacetamide prior to resolving by SDS-PAGE on $10 \%$ acrylamide gel.

\section{Western blotting}

For conventional Western blotting, $20 \mu \mathrm{g}$ of protein was loaded and Ponceau S was used to confirm equal loading. After SDS-PAGE on the BioRad Mini-Protean II system, protein was transferred to nitrocellulose membrane (Schleicher and Schuell, Dassel, Germany). Proteins were detected using ECL (Amersham Biosciences).

\section{Gel staining and analysis}

For MALDI TOF $\mathrm{m} / \mathrm{s}$ analysis, gels were stained with colloidal Blue Coomassie (Sigma) according to the manufacturer's instructions. For silver staining, gels were fixed in $40 \% \mathrm{EtOH}, 10 \% \mathrm{HAC}, 50 \% \mathrm{H}_{2} \mathrm{O}$, for $1 \mathrm{~h}$ and then in $90 \% \mathrm{H}_{2} \mathrm{O}, 5 \% \mathrm{EtOH}, 5 \% \mathrm{HAC}$ overnight. Gels were soaked in $1 \%$ gluteraldehyde, $0.5 \mathrm{M}$ sodium acetate for $30 \mathrm{~min}$, washed three times in $\mathrm{H}_{2} \mathrm{O}$, incubated in ammonical silver for 30 min before washing in water and developing in $0.01 \%$ citric acid/ $0.1 \%$ formaldehyde and stopped in $5 \%$ Tris/2\% acetic acid. Gels were scanned on an Epson Expression 1600 pro scanner and analysed using Phoretix 2D-gel analysis programme (Non Linear Dynamics, Newcastle, UK). At least four duplicate gels were matched, normalised and analysed for each time point.

\section{MALDI-TOF mass spectrometry}

For MALDI TOF m/s analysis, spots were homogenised in $25 \mathrm{mM}$ ammonium bicarobonate $/ 50 \% \mathrm{ACN}$, dried in a vacuum centrifuge and resuspended in $0.05 \mu \mathrm{g} / \mu \mathrm{l}$. Trypsin (Roche, Basel, Switzerland) in $25 \mathrm{mM}$ ammonium bicarbonate $/ 5 \mathrm{mM} \mathrm{CaCl}$. Spots were digested at $37^{\circ} \mathrm{C}$ overnight. Peptides were eluted in $50 \% \mathrm{ACN} / 5 \%$ trifluoroacetic acid
(TFA), and concentrated in a vacuum centrifuge. Salt was removed using ZipTips (Millipore, MA, USA) and peptides spotted onto the MALDI TOF target plate in $20 \mathrm{mg} / \mathrm{ml} \alpha$ cyano-4-hydroxy-cinnamic acid in $50 \% \mathrm{ACN} /$ $5 \%$ TFA.

Mass spectrometry was carried using a Voyager-DePro Biospectrometry workstation and Voyager Software (Applied Biosystems, Warrington, UK). MALDI TOF mass spectrometry was performed in reflector mode and a multipoint calibration was carried out. Spectra obtained were matched through ExPasy Peptldent (http://www.expasy.ch) and Protein Prospector MS-Fit (http://www.prospector.ucsf.edu).

\section{Glucose utilisation assays and pentose phosphate pathway analysis}

For both assays $0.5 \times 10^{6}$ cells in $0.5 \mathrm{ml} \mathrm{Krebs} \mathrm{bicarbonate} \mathrm{buffer} \mathrm{were}$ incubated with $\pm 5 \mu \mathrm{g} / \mathrm{ml} \mathrm{VP16}$ for appropriate times and $20 \mu \mathrm{Ci} / \mathrm{ml}$ of 5- ${ }^{3} \mathrm{H}$ glucose (Amersham Biosciences) for $1 \mathrm{~h}$ before harvesting. Reactions were carried out in microassay tubes within sealed scintillation vials at $37^{\circ} \mathrm{C}$. Cells were killed by addition of $0.5 \mathrm{ml} 0.2 \mathrm{M} \mathrm{HCl}$. Glucose utilisation was assayed as described by Ashcroft. ${ }^{47} \mathrm{H}_{2} \mathrm{O}$ production was by calculated by scintillation counting. Appropriate positive and negative (without cells) controls were performed alongside. All samples were counted in triplicate and data shown are typical of three independent experiments.

The analysis of the pentose phosphate pathway was carried out according to the methods of Katz and Wood. ${ }^{48}$ As above, cells were incubated with VP16 for appropriate times and $4 \mu \mathrm{Ci} / \mathrm{ml}$ of either $1-\mathrm{C}^{14}$ glucose or $6-\mathrm{C}^{14}$ glucose was added for $1 \mathrm{~h}$ before harvest. Reactions were carried out in microassay tubes within sealed scintillation vials at $37^{\circ} \mathrm{C}$. Cells were killed by the addition of $0.5 \mathrm{ml} 0.2 \mathrm{M} \mathrm{HCl}$ and $\mathrm{CO}_{2}$ was released by the addition of hyamine hydroxide to the external chamber. ${ }^{14} \mathrm{CO}_{2}$ release was measured using the scintillation counter as above. The percentage of glucose metabolised by the pentose phosphate pathway was calculated according to the methods of Katz and Woods. ${ }^{48}$

All the data shown are representative of at least three independent experiments.

\section{Acknowledgements}

We are grateful to Enterprise Ireland for financial support.

\section{References}

1. Melino G, Bernassola F, Catani MV, Rossi A, Corazzari M, Sabatini S, Vilbois F and Green DR (2000) Nitric oxide inhibits apoptosis via AP-1-dependent CD95L transactivation. Cancer Res. 60: 2377-2383

2. Curtin JF, Donovan M and Cotter TG (2002) Regulation and measurement of oxidative stress in apoptosis. J. Immunol. Methods 265: 49-72

3. Carmody RJ and Cotter TG (2001) Signalling apoptosis:a radical approach. Redox Rep. 6: 77-90

4. Gorman A, McGowan A and Cotter TG (1997) Role of peroxide and superoxide anion during tumour cell apoptosis. FEBS Lett. 404: 27-33

5. McGowan AJ, Fernandes RS, Samali A and Cotter TG (1996) Anti-oxidants and apoptosis. Biochem. Soc. Trans. 24: 299-303

6. Troyano A, Fernandez C, Sancho P, de Plas E and Aller P (2001) Effect of glutathione depeation on antitumour drug toxicity (apoptosis and necrosis) in $\mathrm{U}$ 937 human promonocytic cells. The role of intracellular oxidation. J. Biolog. Chem. 276: 47107-47115 
7. Chevion M, Berenshtein E and Stadtman ER (2000) Human studies related to protein oxidation: protein carbonyl content as a marker of damage. Free Radical Res. 33: S99-S108

8. Levine RL (2002) Carbonyl modified proteins in cellular regulation, aging and disease. Free Radical Biol. Med. 32: 790-796

9. Stadtman ER and Levine RL (2000) Protein oxidation. Ann. N.Y. Acad. Sci. 899: 191-208

10. Wondrak GT, Cervantes-Laurean D, Jacobson EL and Jacobson MK (2000) Histone carbonylation in vivo and in vitro. Biochem. J. 351: 769-777

11. Berlett BS and Stadtman ER (1997) Protein oxidation in aging, disease, and oxidative stress. J. Biolog. Chem. 272: 20313-20316

12. Stadtman ER (1995) Role of oxidized amino-acids in protein breakdown and stability. In: Redox-Active Amino Acids in Biology. St Louis, MO, USA: Elsevier Science and Technology Books, pp. 379-393

13. Dean RT, Fu SL, Stocker R and Davies MJ (1997) Biochemistry and pathology of radical-mediated protein oxidation. Biochem. J. 324: 1-18

14. Stadtman ER and Berlett BS (1999) Reactive oxygen mediated protein oxidation in aging and disease. In Reactive Oxygen Species in Biological Systems Gilbert DJ, ed. New York: Kluwer Academic/Plenum Publishers, pp. 657-675

15. Burcham PC and Kuhan YT (1997) Diminished susceptibility to proteolysis after protein modification by the lipid peroxidation product malondialdehyde: Inhibitory role for crosslinked and noncrosslinked adducted proteins. Arch. Biochem. Biophys. 340: 331-337

16. Keller JN, Gee J and Ding QX (2002) The proteasome in brain ageing. Age. Res. Rev. 1: 279-293

17. Dukan S, Farewell A, Ballesteros M, Taddei F, Radman M and Nystrom T (2000) Protein oxidation in response to increased transcriptional or translational errors. Proc. Nat. Acad. Sci. USA 97 (11): 5746-5749

18. Sitte N, Merker K and Grune T (1998) Proteasome dependent degradation of oxidised proteins. FEBS Lett. 440: 399-402

19. Friguet B and Szweda LY (1997) Inhibtion of the multicatalytic protease (proteasome) by 4-hydroxy-2-nonenal crosslinked protein. FEBS Lett. 405: 21-25

20. Grune T (2000) Oxidative stress, aging and the proteasomal system. Biogerontology 1: 31-40

21. Fucci L, Oliver CN, Coon MJ and Stadtman ER (1983) Inactivation of key metabolic enzymes by mixed-function oxidation reactions: possible implication in protein turnover and ageing. Proc. Nat. Acad. Sci. USA 80: 1521-1525

22. Ma YS, Chao CC and Stadtman ER (1999) Oxidative modification of glutamine synthetase by 2,2' - azobis(2-amidinopropane) dihydrochloride. Arch. Biochem. Biophys. 363: 129-134

23. Aulak KS, Miyagi M, West KA, Massillon D, Crabb JW and Stuehr DJ (2001) Proteomic method identifies proteins nitrated in vivo during inflammatory challenge. Proc. Nat. Acad. Sci. USA 98: 12056-12061

24. Nakamura A and Goto S (1996) Analysis of protein carbonyls with 2,4dinitrophenyl hydrazine and its antibodies by immunoblot in two-dimensional gel electrophoresis. J. Biochem. 119: 768-774

25. Korolainen MA, Goldsteins G, Alafuzoff I, Koistinaho J and Pirttila T (2002) Proteomic analysis of protein oxidation in Alzheimer's disease brain. Electrophoresis 23: 3428-3433

26. Das N, Levine RL, Orr WC and Sohal RS (2001) Selectivity of protein oxidative damage during aging in Drosophila melanogaster. Biochem. J. 360: 209-216

27. Jana CK, Das N and Sohal RS (2002) Specificity of age-related carbonylation of plasma proteins in the mouse and rat. Arch. Biochem. Biophys. 397: 433439

28. Leunda-Casi A, Genicot G, Donnay I, Pampfer S and De Hertogh R (2002) Increased cell death in mouse blastocysts exposed to high D-glucose in vitro: implications of an oxidative stress and alterations in glucose metabolism. Diabetologia 45: 571-579
29. Colussi C, Albertini MC, Coppola S, Rovidati S, Galli F and Ghibelli L (2002) $\mathrm{H}_{2} \mathrm{O}_{2}$-induced block of glycolysis as an active ADP-ribosylation reaction protecting cells from apoptosis. FASEB J. 14: 2266-2276

30. Levine RL (1984) Mixed-function oxidation of histidine residues. Methods Enzymol. 107: 370-376

31. Levine RL, Garland D, Oliver CN, Amici A, Climent I, Lenz A-G, Ann BW, Shaltiel S and Stadtman ER (1990) Determination of carbonyl content in oxidatively modified proteins. Methods Enzymol. 186: 464-478

32. Dalle-Donne I, Rossi R, Milzani A, Di Simplicio P and Colombo R. (2001) The actin cytoskeleton response to oxidants: from small heat shock protein phosphorylation to changes in the redox state of actin itself. Free Radical Bio. Med. 31: 1624-1632

33. Dalle-Donne I, Rossi R, Giustarini D, Gagliano N, Lusini L, Milzani A, Simplicio $P$ and Colombo R (2001) Actin carbonylation: from a simple marker of protein oxidation to relevant signs of severe functional impairment. Free Radical Biol. Med. 31: 1075-1083

34. Neermann J and Wagner R (1996) Comparative analysis of glucose and glutamate metabolism in transformed mammalian cell lines, insect and primary liver cells. J. Cell. Physiol. 166: 152-169

35. Dalle-Donne I, Rossi R, Giustarini D, Milzani A and Colombo R (2003) Protein carbonyl groups as biomarkers of oxidative stress. Clin. Chim. Acta 329: 23-38

36. Starke-Reed PE and Oliver CN (1989) Protein oxidation and proteolysis during ageing and oxidative stress. Arch. Biochem. Biophys. 275: 559-567

37. Starke PE, Oliver CN and Stadtman ER (1987) Modification of hepatic proteins in rats exposed to high oxygen concnetration. FASEB J. 1: 36-39

38. Dukan S and Nystrom T (1998) Bacterial senescence: stasis results in increased and differential oxidation of cytoplasmic proteins leading to developmental induction of the heat shock regulon. Genes Dev. 12: 3431-3441

39. Mohanti BK, Rath GK, Anantha N, Kannan V, Das BS, Chandramouli BA Banerjee AK, Das S, Jena A, Ravichandran R, Sahi UP, Kumar R, Kapoor N, Kalia VK, Dwarakanath BS and Jain V (1996) Improving cancer radiotherapy with 2-deoxy-D-glucose: phase I/II clinical trials on human cerebral gliomas. Int. J. Radiat. Oncol. Biol. Phys. 35: 103-111

40. Gonin-Giraud S, Mathieu AL, Diocou S, Tomkowiak M, Delorme G and Marvel J (2002) Decreased glycolytic metabolism contributes to but is not the inducer of apoptosis following IL-3-starvation. Cell Death Differ. 9: 1147-1157

41. Aki T, Mizukami Y, Oka Y, Yamaguchi K, Uemura K and Fujimiya T et al. (2001) Phosphoinositide 3-kinase accelerates necrotic cell death during hypoxia. Biochem. J. 358 (Part 2): 481-987

42. Van der Heiden MG, Plas DR, Rathmell JC, Fox CJ, Harris MH and Thompson CB (2001) Growth factors can influence cell growth and survival through effects on glucose metabolism. Mol. Cell. Biol. 21: 5899-5912

43. Gottlob K, Majewski N, Kennedy S, Kandel E, Robey RB and Hay N (2001) Inhibition of early apoptotic events by Akt/PKB is dependent on the first committed step of glycolysis and mitochondrial hexokinase. Genes Dev. 15 $1406-1418$

44. Healy DA, Watson RW and Newsholme P (2002) Glucose, but not glutamine, protects against spontaneous and anti-Fas antibody-induced apoptosis in human neutrophils. Clin. Sci. (London) 103: 179-189

45. Halicka HD, Ardelt B, Li X, Melamed MM and Darzynkiewicz Z (2002) 2-Deoxyd-glucose enhances sensitivity of human histiocytic lymphoma u937 cells to apoptosis induced by tumor-necrosis- factor. Cancer Res. 55 (2): 444-449

46. Zhou R, Vander Heiden MG and Rudin CM (2002) Genotoxic exposure is associated with alterations in glucose uptake and metabolism. Cancer Res. 62: 3515-3520

47. Ashcroft SJL, Weerasinghe JM, Bassett JM and Randle PJ (2002) The pentose cycle and insulin release in mouse pancreatic islets. Biochem. J. 126: 525-532

48. Katz J and Wood HG (1963) The use of C1402 yields from glucose-1- and -6$\mathrm{C} 14$ for the evaluation of the pathways of glucose metabolism. J. Biolog. Chem. 238: $517-523$ 